\title{
Administrative Decisions in the Era of Artificial Intelligence
}

\section{Introduction}

In the era of developing public administration, the next stage is coming closer, so that paper administration, which was only helped by the computer, is moving forward. Editorial programs, judgement search engines, and programs preparing decisions within a certain scheme, are tools that are already used by many public administration employees. Alongside the tools that help in the decision-making process in the broader sense, the use of programmes that require only the signature of an authorized person and for it to be sent to the party is increasingly growing. So they are programmes that issue decisions in a quasi-automatic way. In addition, technological capabilities allow the preparation of such software which will prepare a decision based on a request made by a party, without the additional participation of an official. The automated decision-making process is another challenge that Polish public administration faces, due to the rapid increase in computing power, the development of machine learning by computer programs, and the ability to process huge amounts of unstructured data.

Some perceive the automation of decision-making processes as an advantage, a chance for a fairer, faster and more accurate operation of the administration, both public and private. On the other hand, the others indicate that automatic decision-making programs are as defective and unreliable as human beings, because it is human beings, with all their prejudices, incomplete knowledge, views and horizons who de- 
sign these solutions. The question arises of what factors/conditions, from a legal point of view, are crucial for automatic decision-making to be implemented in administrative proceedings? Moreover, it is interesting what values of administrative law in the broad sense should be taken into account in the process of designing algorithms that serve the citizen in contacts with public administration. Investigation in order to provide answers would have to be very broad if a comprehensive and holistic solution to the problem is to be found, but in this article the study will be narrowed down. The research for the above questions will be reduced to an analysis of the provisions on administrative procedure in the broader sense, and a review of the doctrine's perspectives in this area, supplemented by the views of other fields of science.

\section{The Traditional Model of Administrative Proceedings}

Public administration, in exercising its competences, operates under strictly legal forms in which it is particularly important to issue administrative acts. This activity is the result of administrative proceedings, which are considered to be a sequence of procedural activities undertaken by public administration bodies, in the functional meaning, in order to resolve an individual case in the form of an administrative decision, as defined by the law. ${ }^{1}$ The doctrinal definition of administrative proceedings correlates with the subject matter of the Code, which was defined in Article 1 of the Polish Code of Administrative Procedure and includes, inter alia, proceedings before public administration bodies in individual cases, which are within the competence of those bodies and are either resolved by administrative decisions or by a silent settlement. With the exception of certain autonomous exceptions, the administrative procedure carried out by a public administration body shall be governed by strict rules, which

1 B. Adamiak, Zagadnienia ogólne procesowego prawa administracyjnego, in: System Prawa Administracyjnego, vol. IX: Prawo procesowe administracyjne, Warszawa 2010, p. 6. 
derive mainly from the Polish Code of Administrative Procedure. ${ }^{2}$ In some situations, the legislator has decided that, due to the specific subject matter of the regulation, it is necessary to introduce different, complementary rules of conduct in cases which result in an administrative decision. Examples include proceedings in construction, social assistance and tax matters, which nevertheless make greater or lesser reference to the provisions of the Polish Code of Administrative Procedure.

The procedure regulated by Polish law specifies the actions that may be taken by a public administration body in order to exercise its competence under the Polish substantive law and, which is important from the individual's point of view, to protect them against excessive interference by the public administration. It should be borne in mind that the administrative procedure is aimed at implementing the norms of substantive administrative law and is closely related to them. ${ }^{3}$ The addressees of the provisions are, on the one hand, public administration bodies, or entities which carry out administrative authority but are not necessarily part of the public administration structure, and on the other hand, there are entities interested in a specific decision due to their right or obligation. Moreover, other entities may participate in the proceedings, such as an expert or a witness, but their role is incidental and temporary. Thus, we have clearly defined subjects of administrative proceedings.

If a public authority is to act in the context of an administrative procedure, it must determine whether three basic premises are met, which are:

1) an entity which is an addressee of a substantive law norm, called an administered entity;

2) the competence, defined by law, of an entity performing the function of a public administration body, which is an administrative entity;

2 The Code of Administrative Procedure, Journal of Laws of 2020, item. 256, further: Code of AP.

3 R. Hauser, Rola przepisów procesowych w realizacji norm materialnego prawa administracyjnego, in: Rola materialnego prawa administracyjnego a ochrona praw jednostki, in ed. Z. Leoński, Poznań 1998, pp. 23-24. 
3) the possibility of settling the matter by means of an administrative decision or by silent settlement.

Preliminary verification of the requirements being met permits further actions to be taken, starting from the formal initiation of proceedings and ending with a legal decision.

The legal and factual acts undertaken by an authority shall constitute administrative proceedings of jurisdiction. ${ }^{4}$ In the simplified model, the general administrative proceedings can be described as a general administrative procedure with two modes - general proceedings and extraordinary proceedings. ${ }^{5}$ Within general proceedings, we distinguish proceedings before the body of first instance and, if an appeal against the decision is lodged, proceedings before the body of the second instance. On the other hand, the subject of extraordinary proceedings is the verification of the decision issued by the body of first or second instance.

There are three stages in general and extraordinary administrative proceedings: an initial stage, an explanatory stage, and a settlement stage. Material, technical and process activities are undertaken at all stages. Technical activities are understood to include, among other things, the physical acceptance of an application or other paperbased letter, acknowledgement of receipt or submission of the letter, the sending of the letter or, for example, visual inspection or measurement during a direct examination carried out using the senses. Procedural actions may concern the assessment of the application submitted in formal terms, e.g. with regard to the origin of the party or other entitled entity, the timeliness of the submission of the letter or statement for the minutes, or the payment of a fee, if provided for by law. These side actions, as a whole, are aimed at creating an administrative act. Important steps include establishing the facts, which often take the form of official

\footnotetext{
4 J. Zimmermann, Polska jurysdykcja administracyjna, Warszawa 1996, p. 6.

5 B. Adamiak, Koncepcja nadzwyczajnych trybów postępowania administracyjnego, “Acta Universitatis Wratislaviensis” 1985, no. 648, Prawo CXII, p. 91 and further.
} 
documents in the course of administrative proceedings, determining the substantive rules relating to the administrative matter in question and activities relating to the subsumption of the evidence gathered in the light of the legal status of the case. An administrative act, resulting from a logical conclusion based on facts and legal norms, is a process of thought. For the major part, the public administration applies on the basis of such legal norms which leave no room for any margin of manoeuvre in a given actual state. In other words, the State, acting through public plenipotentiaries, is limited in the way it chooses to act and is obliged to issue a related administrative act.

The opposite to this group of administrative acts are decisions taken in a discretionary manner. The study of administrative law indicates that a public authority, acting within the framework of administrative discretion, has the possibility to choose the legal consequences of an act based on a specific legal norm. ${ }^{6}$ The blanket provision provides a fully developed hypothesis, while the disposition takes the form of a disjunction, which makes it possible to determine the content of the decision by the authority. ${ }^{7}$ This power is the final stage in the law's implementation in the course of administrative proceedings, after subsuming, in which the authority makes the choice of legal effects. ${ }^{8}$

The problem of the decision-making autonomy granted to public administration bodies is also related to the issue of vague, value-adding concepts, which, according to some, meet the broad concept of administrative discretion. ${ }^{9}$ In contrast, Jaśkowska submits that vague concepts, including estimates, that are present in the norm are subject to interpretation of the law, and are therefore involved at a different stage of application of the law in the process of taking a decision. ${ }^{10}$ The de-

6 J. Zimmerman, Prawo administracyjne, Warszawa 2008, p. 304.

7 A. Błaś, Prawo administracyjne, ed. J. Boć, Wrocław 2010, pp. 332-336.

8 J. Zimmerman, Prawo administracyjne, Warszawa 2020, pp. 304-307.

9 T. Bąkowski, Administracyjnoprawna sytuacja jednostki w świetle zasady pomocniczości, Kraków 2007, pp. 159-161.

10 M. Jaśkowska, Pojęcie uznania administracyjnego, in: System Prawa Administracyjnego, vol. I: Instytucje prawa administracyjnego, Warszawa 2009, p. 254. 
limitation of administrative recognition from related decisions based on vague normative concepts is important, as the scope of the control of free administrative acts is different since, in principle, it is limited in nature and it is assumed that the courts examine only the question of their legality and not the grounds of equity. ${ }^{11}$ At the same time, it should be stressed that the administrative courts, in their extensive rulings, have a significant influence on the understanding of the general clauses, their delimitation and the relationship of administrative discretion in relation to standards containing vague concepts. ${ }^{12}$

Administrative acts, whether binding or casual, are issued on the basis of and within the legal limits, which is a consequence of the constitutional principle of the rule of law, as defined in Article 7 of the Constitution of the Republic of Poland, subsequently repeated in Article 6 of the Code of Administrative Procedure. As Zimmermann argues, the principle of legality is a rudimentary general principle of administrative procedure under the rule of law, taking priority over other rules of procedure. ${ }^{13}$ It is the sources of universally binding law that define the boundaries of the public administration's activity, both in the sphere of non-governmental administration and, most importantly, also in the sphere of the government's activity. The question arises here of whether the transformations of public administration, especially of a technical nature, and the computerisation of administrative proceedings can be considered as such, have a sufficient legal basis, and whether the established law does not create a kind of barrier in further improvement or evolution of the Polish public administration. Since the principle of prompt and simple administrative procedure, expressed in Article 12 of the Code of Administrative Procedure, is one of the general principles of adminis-

11 Ibidem, p. 288.

12 T. Bąkowski, Udział sq̨dów administracyjnych w kształtowaniu pojęć i konstrukcji prawa administracyjnego, in: Orzecznictwo w systemie prawa. II Konferencja Naukowa Wydziału Prawa i Administracji Uniwersytetu Gdańskiego i Wolters Kluwer Polska, eds T. Bąkowski, K. Grajewski, J. Warylewski, Warszawa 2008, p. 188.

13 J. Zimmermann, Glosa do wyroku SN z dnia 23 lipca 1992 r., sygn. akt III ARN 40/92, "Państwo i Prawo" 1993, no. 8. 
trative procedure, it would seem that new technical solutions, especially the current progress in the sphere of machine learning and automatic data processing, will be a remedy for the weaknesses of modern public administration. Particularly as the principle of efficiency, also called the principle of effectiveness, appears in the Preamble to the Polish Constitution. However, it should be stressed that it does not take priority over the principle of legalism, nor does it imply an agreement to restrict the rights of an individual in its name. ${ }^{14}$ Nevertheless, it is important to note that justice delayed is justice denied ${ }^{15}$, and therefore in accordance with the law, a State decision delivered within a reasonable short period of time is an affirmation of the rule of law and an implementation of this principle of efficiency.

\section{Areas of the Computerisation and Automation of Public Administration}

Searching for answers to the problems of the Polish public administration, such as poor efficiency or excessive bureaucracy, in the process of computerization seems to be a natural and rational action. For many of us, a visit to a bank is a distant memory, the Internet is the basic form of communication in our business, and on-line shopping is no longer just a fashion, but a necessity. Still, to ensure that effective IT evolution, or a revolution, takes place in the Polish public administration, and especially in the area of administrative proceedings, it is worth determining whether it will take place on the basis and within the boundaries of the law.

The computerisation of administrative proceedings has been going on for a long time, however, the solutions adopted theoretically facilitate access to and from the authority by means of electronic communication with the complementary elements of identification in a virtual reality.

14 Wyrok Trybunału Konstytucyjnego z 25 września 2014 r., SK 4/12, OTK-A 2014, No. 8, pos. 95.

15 A. Redelbach, Sqdy a ochrona praw człowieka, Toruń 1999, p. 279. 
Progressive digitalization supports technical operations, accelerates and facilitates certain activities. However, it does not cover the most important stage, namely the resolution itself, and the lack of widespread use of electronic identification effectively limits further use of this technology.

The evolutionary changes made to the computerisation of administrative procedure by its limited scope to the technical sphere do not significantly affect the process of remote settlement. As Sibiga argues, the solutions adopted are not consistent and are not fully coordinated by the governmental entities involved in the legislative process. ${ }^{16}$ Maybe that is why the computerisation of public administration affects only technical regulations, and the electronic procedure has not gone beyond the text editor. Nevertheless, certain technical and legal solutions may be considered to be crucial in the sphere of computerisation of public administration and support for its operation, and in particular for resolving individual cases by automatic processes.

The digitalization of procedures and the introduction of IT tools has led to some kind of quasi-automated decision making. An example is the decision setting the real estate tax for natural persons issued pursuant to Article $21 \S 1(2)$ of the Tax Ordinance Act ${ }^{17}$ in conjunction with Article $6 \S 7$ of the Local Tax and Charges Act. ${ }^{18}$ Every year between January and March, thousands of such tax decisions are issued by the executive bodies in all Polish municipalities. They use computer programs which, on the basis of the taxpayers' records, including data on the subjects of taxation, rates and tax base, determine the amount of real estate tax. In general, the only variable for most natural persons in a given year is the tax rate, so the decision is based on the data available. It is not possible to issue several or several thousand decisions at once in a short period of time using the full model of tax case resolution. In fact,

16 G. Sibiga, Stosowanie technik informatycznych w postępowaniu administracyjnym ogólnym, Warszawa 2019, pp. 79 and 236.

17 Ustawa z 29 sierpnia 1997 Ordynacja podatkowa, Journal of Laws of 2019, item 900.

18 The Local Tax and Charges Act, Journal of Laws of 1991, no. 9, item 31, which is Journal of Laws of 2019, item 1170. 
when printed, the decisions are signed by the office holder of the body or a person authorized by him/her. The correctness is verified at the initial stage when the updated rates are checked. There is no time nor technical possibility for each decision to be checked before it is signed by an authorised entity. The same applies if an additional charge is imposed as a result of a parking fee not being paid. New technological solutions make it possible to control the payment of charges by means of the camera system fixed to the cars that take pictures of the licence plates, to decode from the pictures of the licence plate number, to compare it with the database of the vehicles' licence plates for which the parking charge was paid, and then to prepare a document calling for an additional charge for the parking fee not being paid. ${ }^{19}$ According to an official of the Municipal Roads Administration in Warsaw, “...the role of a man is to put a call in the envelope and seal it, and then dispatch it..."20 Such an action - issuing a decision or a call by the programme - is not fully reflected in the law, so in order to maintain the formalism of the Code of Administrative Procedure an official signs a decision or other letter. Therefore, already today a computer program basically replaces human beings and makes a decision on their behalf, while the signature is a legal fiction, which, due to the formalism of tax or other proceedings, must be observed.

The automation of activities looming on the horizon, or more precisely Automated decision making - $A D M$ means making a decision/resolution without any human involvement. Instead of the human being and the evidence-based "thinking” process, unaggregated data is taken by a computer program equipped with an appropriate algorithm. Artificial intelligence is responsible for a given final result of the data analysis based on certain rules. These rules can be economic indicators, medical

19 More about e-audits see P. Pieńkosz, E-kontrole jako narzędzie rozwoju stref płatnego parkowania w miastach na prawach powiatu. Szanse i problemy, "Monitor Prawniczy” 2019, no. 24.

20 Rusza e-kontrola w Warszawie. Coraz łatwiej o mandat za parkowanie, <https://spidersweb.pl/autoblog/strefa-platnego-parkowania-warszawa-e-kontrola/>. 
quantifiers, or the law, which is itself a rule of conduct, and therefore an algorithm. It is crucial, that a computer program prepares the final solution on the basis of the output data, without human intervention. The technical possibilities of using ADM have expanded considerably, even by leaps and bounds, and thus seem to be created for use by public authorities in repetitive activities.

The progress in machine learning and the possibility of using large and diverse sets of variable data - Big Data - allows for a wide use of artificial intelligence in decision-making processes. Most often, within the $\mathrm{ADM}$ framework a distinction is made between processes that are relatively simple in nature, processes that are more complex in nature, and processes that require abstract thinking. Wiewiórowski and Sibiga, on the other hand, suggested dividing the automation systems into three types: automation based on simple algorithms, specialist automation, and the automation of discretionary decisions. ${ }^{21}$ The most interesting for the Polish administrative law are solutions developed within complex algorithms and those including abstract elements. It should be remembered, however, that administrative law is not a binary code that can be easily and simply algorithmized $^{22}$, but a law that serves the collective and individual needs of citizens resulting from the coexistence of people in communities ${ }^{23}$, with all the axiological, cultural and social baggage that will or will not be possible to convert into a binary code, and thus to automate administrative processes.

The use of simple algorithms in administrative proceedings seems the easiest to implement. The issuing of certificates, the provision of material aid in a situation where it is sufficient to check whether the applicant meets the conditions for obtaining social benefit, for example,

21 G. Sibiga, W. Wiewiórowski, Automatyzacja rozstrzygnięć i innych czynności w sprawach indywidualnych załatwianych przez organ administracji publicznej, in: Informatyzacja postępowania sq̨dowego i administracji publicznej, ed. J. Gołaczyński, Warszawa 2010, p. 231.

22 W. Bateman, Algorithmic Decision-Making and Legality: Public Law Dimensions, “Australian Law Journal”.

23 J. Boć, Pojęcie administracji, in: Prawo administracyjne..., p. 15. 
does not require any significant legislative changes. In this case, it is more a matter of mental changes among administrative decision-makers and the preparation of small technical solutions only. The so-called $500+$ Programme may serve as a good example of a quick transformation into an automatic process, without the use of the human factor. By means of e-banking and other electronic channels, about 25\% of applications for support were submitted in 2016, while in 2018 almost 50\% of on-line applications for support were submitted. ${ }^{24}$ The Programme itself, implemented on the basis of the Act on State aid in raising children $^{25}$ in the binding wording, allows, apart from a few special situations, to grant support to a parent or legal guardian of a child - see Article 4(2) of the said Act. Unfortunately, the on-line application alone did not result in a decision in the form of an electronic document. In the majority of cases, the public administration body had to issue and deliver an administrative decision in the traditional form - i.e. on paper, delivered by post with a receipt confirmation. This was a consequence of the legal solutions adopted, in which the entitled person could submit an application electronically, but unfortunately the administrative authority was not authorised to issue a decision in an electronic form. It is possible to receive an electronic decision if an application is made by means of an electronic application mailbox of a public administration body, which follows from art. $391 \S 1$ point 1 of the Code of Administrative Procedure, but only few entitled persons decide to do so. In contrast, the 500+ Act provides a possibility, among other things, to submit applications using the ICT system of domestic banks providing services by electronic means that meet the requirements set by the minister competent for family affairs, after agreement with the minister competent for computerisation - Article 13 section 5 of the $500+$ Act. In

24 <https://www.gov.pl/web/rodzina/2-mln-wnioskow-rodzina-500-plus>; <https://wiadomosci. dziennik.pl/polityka/artykuly/584513,wnioski-online-500-plus-300-plus-polacy-rodzinadane.html>.

25 Ustawa o pomocy państwa w wychowywaniu dzieci from 11 of February, Journal of Laws of 2019, item 2407. 
this model, verification takes place by means of authentication of the applicant using the credentials used by the national bank for verification by electronic means of the account holder. This solution does not meet the requirements of submitting an application through the ePUAP or signing the decision with a qualified electronic signature. The 2019 amendment improved the hybrid solution, because in the light of the current Article 13a of the above-mentioned Act, a decision is not required at all, and granting a benefit is a material and technical act.

The analysis of the settlement in the 500+ cases allows some conclusions to be drawn concerning the computerisation and automation of the public administration. Undoubtedly, the actions taken have not been fully correlated with the whole system of the law in force, especially with the central administrative office, and the adopted solutions of the possibility to submit applications via ICT banking systems are a kind of a system latch, which has been designed for this project. The large-scale use of non-public systems for identification in matters related to public services shows that the adoption of simple, friendly solutions, such as authentication in banking systems, is a direction for further actions in the field of computerization of public administration. On the other hand, it can be considered that a simple decision-making process, where in mos cases the benefit is granted, would allow the use of simple algorithms which would identify the applicant and grant the benefit to the entitled persons automatically, without human intervention. In a situation where the number of applications is counted in millions, and the same number of applications are accepted, the use of decision-making algorithms has significantly accelerated proceedings, streamlined the payment of benefits and reduced the personnel costs of public administration.

To sum up, the assumption that the granting of benefits is currently of a material and technical nature only confirms the thesis on the possibility of using artificial intelligence in decision-making processes carried out by public administration. Similarly, the formal recognition of these quasi-automatic processes carried out within the context of an additional 
charge for parking or the setting of a property tax for individuals as acceptable would fully improve the efficiency of the measures taken and reduce the costs of operating the system in this respect, while the whole procedure would be lega artis.

The application of ADM in administrative processes of a complex nature is clearly a challenge, but not impossible. Since autonomous vehicles are able to adapt their speed to the circumstances of highly variable road conditions, such as traffic density, weather conditions or traffic reorganisation, the more complex decision-making processes will be solvable by means of artificial intelligence. Undoubtedly, as in the case of simple algorithms, it will help to use machine learning. It is such use of algorithms that draws on the experience of the past and, at the same time, by analysing it, improves its operations. The program should take into account the indications of the programmer-teacher, previous learning, and the analysis of the results of their work generated by themselves. Learning programmes are repeatedly tested in laboratories, or in the real world, before they are widely used. The idea is to detect behavioural patterns, trends in previous decisions, and at the same time, to adapt to changes taking place in the environment they work in. The processing of large knowledge resources allows the programme to learn effectively which actions should be taken in a particular case.

The public administration has a huge amount of data in its resources. Millions of decisions issued by first and second instance authorities and decisions by administrative courts have existed for years in electronic form. The huge database allows for the analysis of the line of jurisprudence, as well as the correctness of decisions, in terms their features and language, and, most importantly, apart from justifications for decisions or rulings, analysis of the sentences of decisions in many administrative cases. We already use the results of artificial intelligence, including machine learning, when using legal programs to support the decision making process or when searching the portal with administrative court de- 
cisions. This huge database and today's machine learning capabilities even encourage this direction of legal informatics development.

Initially, the artificial intelligence law programs could be used to support the decision-making process while testing solutions. After this period, in certain areas the decision-making processes of officials could be gradually replaced by legal algorithms and automatic decisions. In repetitive activities, e.g. analysing agreements in terms of legal risks and securing the interests of the parties, it is also worthwhile to use computer programs that have already proved to be better than professional lawyers. As an example of AI's superiority over human beings, a study can be cited, in which lawyers checked five contracts in 92 minutes and reached an 85\% accuracy factor, and a computer program analysed the same contracts for 23 seconds at $94 \%$ efficiency. ${ }^{26}$ This means that from a technical point of view, we are able to prepare applications that would replace or significantly eliminate the human factor from the decision-making process.

The cited examination of contracts for the protection of client interests and legality differs from the administrative decision-making process, but these differences seem to be quite relative. Both of them concern the decoding of a legal norm in a specific factual situation. The commensurability of activities in the civil and public spheres is not such a significant difference that artificial intelligence solutions in the administrative process should be rejected. In the case of the public administration, the axiology of administrative law, so important in the process of decoding norms of substantive law, will be fundamental. Administrative decisions based on value-added rules, or those based on administrative recognition, remain a challenge for many. Converting them or preserving the axiology of administrative law in automatic decision-making processes will be a challenge, but it will be possible in the near future.

Artificial intelligence based on existing decisions and rulings could search how an authority or a court understands a given concept that is not

$26<$ https://cacm.acm.org/news/233886-ai-removes-the-drudgery-from-legal-due-diligence/ fulltext $>$. 
defined in binary terms. General clauses, references to non-legal norms or undefined concepts require an operative interpretation in a specific case. ${ }^{27}$ At this point the problem of subjectivity in human interpretation arises, as well as its impact on the effects of the interpretation undertaken. ${ }^{28}$ The decisions taken by a person acting as a judge or a public administration body are also influenced by his/her mental state, health and even the state of satiety. ${ }^{29}$ Moreover, the bias of the algorithms is clearly mentioned among the problems associated with using artificial intelligence. If the input data - the administrative decisions already included in the databases - have a subjective element, the touch of the digital wand will not change the decisions made so that they will be automatically fair, unbiased, objective and lawful. In short, if the input is biased, the output - the expected decisions will also be biased..$^{30}$ In the machine learning, the data is everything ${ }^{31}$, so poor quality (decisions and judgements) will result in faulty results of automatic processes. Therefore, when designing the algorithm, it is necessary to take into account these risks and choose modelling methods that take into account equality issues, such as the FairKM model proposed by Deepak Padmanabhan. ${ }^{32}$ The adoption of automated decision-making systems to replace the human factor eliminates the risk of prejudice and bias. ${ }^{33}$ At the same time, the data should be selected or

27 M. Jaśkowska, Pojęcie uznania administracyjnego, p. 301.

28 Z. Duniewska, Wybrane aspekty wykładni prawa administracyjnego (racje i właściwość), in: Koncepcja systemu prawa administracyjnego, ed. J. Zimmermann, Warszawa 2007, p. 667.

29 S. Danzigera, J. Levavb, L. Avnaim-Pessoa, Extraneous factors in judicial decisions, $<$ http://www.pnas.org/cgi/doi/10.1073/pnas.1018033108>.

30 M. Finck, Automated Decision-Making and Administrative Law, <https://ssrn.com/abstract $=3433684,2019>$.

31 L. Jason Anastasopoulos, A.B. Whitford, Machine Learning for Public Administration Research, with Application to Organizational Reputation, "J. Pub. Admin. Res. \& Theory" 2018, no. 16.

32 S.S. Abraham, P. Deepak, S. Sundaram, Fairness in Clustering with Multiple Sensitive Attributes, 2020, <http://arxiv.org/abs/1910.05113>.

33 T. Zarsky, The trouble with algorithmic decisions: an analytic road map to examine efficiency and fairness in automated and opaque decision making, "Science, Technology \& Human Values” 2016, no. 41(1). 
pre-processed in such a way that poor or biased quality does not result in the duplication of errors by persons acting as authorities.

Studies on the use of algorithms clearly indicate that, in addition to fairness, the algorithms that are developed must take into account the transparency of the decision-making process. As in the case of a classic decision, where we are able to trace the stages of the administrative process and to some extent reproduce the thought process of the person preparing the administrative decision, it is expected that it will also be possible to repeat this action against automated processes. Therefore, already at the stage of designing a program used in automatic processes, it is necessary to create such procedures which will make it possible to explain, in a transparent way, on the basis of which patterns the program has acquired experience. In our Polish case, the starting point will be the law established in accordance with the rule of law and the existing set of decisions and rulings issued in lega artis. Transparency is an important factor in the assessment and acceptance of automatic decision-making ${ }^{34}$, as it inspires confidence in the entity using AI and thus in artificial intelligence itself. Lack of acceptance of AI actions, based on automatic processes, will result in a loss of trust in public administration, which will then undermine the actions of public authorities and delegitimize the sense of the state itself. It should be noted that ADM cannot be a black box in which an enigmatic algorithm prepares ready-to-use solutions for people who have to comply with it. After all, as O’Neill writes, the transcription of words into records, which are then stored in algorithms that are understood by a narrow elite ${ }^{35}$, carries the danger of exclusion, bias and prejudice. The transposition of the law into digital, verbatim, will not allow for an explanation of what has skewed the scales for this and no other decision. The risk of non-transparency in automated pro-

34 L. Floridi, J. Cowls, M. Beltrametti, R. Chatila, P. Chazerand, V. Dignum, B. Schafer, AI4People-An ethical framework for a good AI society: opportunities, risks, principles, and recommendations, "Mind Mach” 2018, no. 28(4).

35 C. O’Neil, Weapons of math destruction: how big data increases inequality and threatens democracy, Broadway Books, New York 2016, p. 25. 
cesses is enormous and will not only be a violation of the principle of persuasion expressed in art. 11 of the Code of Civil Procedure, but it will also constitute a breach of the entire social system and the essence of humanity. Therefore, when preparing activities using ML and ADM, it is necessary to use data resources and such algorithms that will allow it to be completely eliminated. The transparency of automatic processes also results in the legitimacy of administration and state activities. After all, a fair administrative decision issued quickly, in accordance with the law and understandable both linguistically and from the point of view of the motives of the State will increase public trust in the state. ${ }^{36}$

\section{Conclusions}

Already existing IT capabilities and the development of computing power have triggered a leap in the capabilities of artificial intelligence based on machine learning. These elements allow for the extensive development of programs that will be able to replace humans in decision making. Automated decision-making processes save time, issue decisions in accordance with the law, and thus assist the public administration in its tasks. Undoubtedly, administrative proceedings based on procedural decision-making rules are the first group where ADM is possible. This requires a simple adaptation of the provisions mainly concerning the identification of parties in a friendly, generalised manner, so that the benefits of electronic communication are actually visible, as is the case with electronic banking.

The greater challenge is to make administrative decisions that are based on valuation rules, general clauses and administrative recognition. Theoretically, machine learning can break this barrier, but introducing automatic solutions in this area requires some testing and checking if the algorithms are able to work not only objectively and legally, but also

36 C. Coglianese, D. Lehr, Transparency and algorithmic governance, "Administrative Law Review” 2019, <https://ssrn.com/abstract=3293008>. 
in accordance with the values presented by the public administration, such as transparency, equality, justice and others. Past experience shows that algorithms are as subjective as the designers who create them. That is why it is important to put the above-mentioned explanations on an equal footing - the point is that everyone should be able to say why a public administration body made this decision and not another. In other words, an artificial intelligence making automatic decisions on behalf of the State cannot be a black box that generates a decision, but must be a tool that supports the execution of public tasks for the citizens.

\section{References}

Abraham S.S., Deepak P., Sundaram S.S., Fairness in Clustering with Multiple Sensitive Attributes, 2020, <http://arxiv.org/abs/1910.05113>. Adamiak B., Koncepcja nadzwyczajnych trybów postępowania administracyjnego, “Acta Universitatis Wratislaviensis” 1985, no. 648, Prawo CXII.

Adamiak B., Rozdział I. Zagadnienia ogólne procesowego prawa administracyjnego, in: System Prawa Administracyjnego, t. IX: Prawo procesowe administracyjne, Warszawa 2010.

Anastasopoulos L.J., Whitford A.B., Machine Learning for Public Administration Research, with Application to Organizational Reputation, “J. Pub. Admin. Res. \& Theory” 2018, no. 16.

Bąkowski T., Administracyjnoprawna sytuacja jednostki w świetle zasady pomocniczości, Kraków 2007.

Bąkowski T., Udział sq̨dów administracyjnych w kształtowaniu pojęć i konstrukcji prawa administracyjnego in: Orzecznictwo w systemie prawa. II Konferencja Naukowa Wydziału Prawa i Administracji Uniwersytetu Gdańskiego i Wolters Kluwer Polska, eds T. Bąkowski, K. Grajewski, J. Warylewski, Warszawa 2008.

Bateman W., Algorithmic Decision-Making and Legality: Public Law Dimensions, “Australian Law Journal” 2019. 
Błaś A., Prawo administracyjne, ed. J. Boć, Wrocław.

Coglianese C., Lehr D., Transparency and algorithmic governance, “Administrative Law Review” 2019.

Danzigera S., Levavb J., Avnaim-Pessoa L., Extraneous factors in judicial decisions, <http://www.pnas.org/cgi/doi/10.1073/pnas.1018033108>.

Duniewska Z., Wybrane aspekty wykładni prawa administracyjnego (racje i właściwość), in: Koncepcja systemu prawa administracyjnego, ed. J. Zimmermann, Warszawa 2007.

Finck M., Automated Decision-Making and Administrative Law, 2019, $<$ https://ssrn.com/abstract=3433684>.

Floridi L., Cowls J., Beltrametti M., Chatila R., Chazerand P., Dignum V., Schafer B., AI4People-An ethical framework for a good AI society: opportunities, risks, principles, and recommendations, "Mind Mach” 2018, 28(4).

Hauser R., Rola przepisów procesowych w realizacji norm materialnego prawa administracyjnego, in: Rola materialnego prawa administracyjnego a ochrona praw jednostki, ed. Z. Leoński, Poznań 1998.

$<$ https://cacm.acm.org/news/233886-ai-removes-the-drudgery-fromlegal-due-diligence/fulltext $>$.

$<$ https://www.gov.pl/web/rodzina/2-mln-wnioskow-rodzina-500-plus>. $<$ https://wiadomosci.dziennik.pl/polityka/artykuly/584513,wnioski-online-500-plus-300-plus-polacy-rodzina-dane.html>.

Jaśkowska M., Pojęcie uznania administracyjnego, in: System Prawa Administracyjnego, vol. I: Instytucje prawa administracyjnego, Warszawa 2009.

Kodeks postępowania administracyjnego, tekst jedn.: Journal of Laws of 2020, item 256.

O'Neil C., Weapons of math destruction: how big data increases inequality and threatens democracy, Broadway Books, New York 2016.

Pieńkosz P., E-kontrole jako narzędzie rozwoju stref płatnego parkowania w miastach na prawach powiatu. Szanse i problemy, "Monitor Prawniczy” 2019, no. 24. 
Redelbach A., Sqqdy a ochrona praw człowieka, Toruń 1999.

Rusza e-kontrola w Warszawie. Coraz łatwiej o mandat za parkowanie, $<$ https://spidersweb.pl/autoblog/strefa-platnego-parkowaniawarszawa-e-kontrola/>.

Sibiga G., Stosowanie technik informatycznych w postępowaniu administracyjnym ogólnym, Warszawa 2019.

Sibiga G., Wiewiórowski W., Automatyzacja rozstrzygnięć i innych czynności w sprawach indywidualnych załatwianych przez organ administracji publicznej, in: Informatyzacja postępowania sqdowego i administracji publicznej, ed. J. Gołaczyński, Warszawa 2010.

Ustawa o podatkach i opłatach lokalnych, Journal of Laws of 1991, no. 9, item 31, which is Journal of Laws of 2019, item 1170.

Ustawa o pomocy państwa w wychowywaniu dzieci z dnia 11 lutego 2016, Journal of Laws of 2019, item 2407.

Ustawa z 29 sierpnia 1997 Ordynacja podatkowa, Journal of Laws of 2019, item 900.

Wyrok Trybunału Konstytucyjnego z 25.9.2014 r., SK 4/12, OTKA 2014, Nr 8, poz. 95.

Zarsky T., The trouble with algorithmic decisions: an analytic road map to examine efficiency and fairness in automated and opaque decision making, "Science, Technology \& Human Values" 2016, no. 41(1), SAGE Publications Sage CA: Los Angeles, CA.

Zimmerman J., Prawo administracyjne, Warszawa 2008.

Zimmermann J., Glosa do wyroku SN z dnia 23 lipca 1992 r., sygn. akt III ARN 40/92, "Państwo i Prawo” 1993, no. 8.

Zimmermann J., Polska jurysdykcja administracyjna, Warszawa 1996. 


\section{SUMMARY}

\section{Administrative Decisions in the Age of Artificial Intelligence}

The rapid development of cybernetics allows the use of artificial intelligence in many areas of social and economic life. The State can also harness algorithms and machine learning for its actions. Automatic decision making should be one of the stages in the development and improvement of public administration. While it is easy to implement these solutions in the case of related decisions, decisions made under administrative discretion, general clauses or valuation standards pose a challenge. The correct transformation of paper-based public administration into automatic public administration requires a change in decision makers' thinking, the introduction of new solutions, and building trust in artificial intelligence. Therefore, new solutions have to be built in accordance with the principles of transparency, accountability, equality, goodness and justice. Artificial intelligence making automatic decisions on behalf of the State must be a tool to support the execution of public tasks concerning citizens which is based on trust towards AI and public administration.

Keywords: public administration, artificial intelligence, administrative decision, automatic decision making.

Mateusz Pszczyński, Faculty of Law and Administration, Katowicka 87a, 45-060 Opole, Republic of Poland, e-mail: mpszczynski@uni.opole.pl.

DOI 10.14746/ppuam.2020.11.13 
